\title{
HUBUNGAN PENGETAHUAN DAN SIKAP PENDAMPINGAN SUAMI TERHADAP ISTRI DALAM PERSALINAN
}

\author{
Laurena Ginting \\ Dosen Prodi D-III Kebidanan, STIKes Murni Teguh, Jalan Jawa No 2 Gang Buntu Medan \\ Email: Laurenaginting2087@gmail.com
}

\begin{abstract}
ABSTRAK
Selama proses persalinan berlangsung ibu akan mengalami rasa cemas, gelisah, takut, nyeri karena kontraksi yang adekuat, hal tersebut dapat menyebabkan peningkatan katekolamin yang menurunkan efisiensi kontraksi sehingga mempengaruhi lama persalinan berlangsung dan pengurangan darah dari ibu ke janin. Ibu bersalin sangat membutuhkan orang - orang terdekat yang memberikan dorongan dan kasih sayang yang lebih sehingga membantu kelancaran proses persalinan. Tidak semua Rumah Sakit, pelayanan kesehatan lainnya dan suami menyadari pentingnya kehadiran pendamping selama persalinan. Tujuan melakukan penelitian ini untuk mengetahui Hubungan Pengetahuan Dan Sikap Pendampingan Suami Terhadap Istri Dalam Persalinan di Klinik MIMI Tahun 2018. Jenis penelitian ini adalah survei analitik dengan desain Cross Sectional. Jumlah sampel 30 orang dengan teknik pengambilan sampel purposive sampling. Hasil penelitian menunjukkan terdapat hubungan pengetahuan pendampingan suami terhadap istri dalam persalinan dengan nilai Hubungan pengetahuan dan Sikap pendampingan suami dalam persalinan yaitu adanya hubungan pengetahuan dan sikap dalam pendampingan suami istri dalam persalinan dikatahui dengan nilai $p=0.001$ untuk pengetahuan dan $p$ $=0.000$ untuk sikap. Perlu ditingkatkan Pengetahuan dan Sikap suami dalam persalinan karena dengan adanya pendampingan suami membuat ibu bersalin merasa disanyangi dan semakin semangat dalam mengahadapi persalinan. Petugas kesehatan perlu meningkatkan peran suami dalam pendampingan persalainan istri dengan memberikan informasi terkait persalinan dan hal-hal yang diperlukan.
\end{abstract}

Kata Kunci $\quad$ : Pengetahuan, Sikap, Pendampingan Suami, Persalinan

\section{PENDAHULUAN}

Selama proses persalinan berlangsung ibu akan mengalami rasa cemas, gelisah, takut, nyeri karena kontraksi yang adekuat, hal tersebut dapat menyebabkan peningkatan katekolamin yang menurunkan efisiensi kontraksi sehingga mempengaruhi lama persalinan berlangsung dan pengurangan darah dari ibu ke janin (Tarsikah, 2012). Sehingga dapat mengakibatkan komplikasi selama persalinan berlangsung dan bahkan kematian pada ibu dan janin.

Berdasarkan hasil SDKI pada tahun 2012 angka kematian ibu mencapai 359 per 100ribu kelahiran hidup, angka kematian ibu melonjak dibandingkan dengan SDKI 2007 yang mencapai 228 per 100 ribu kelahiran. Menurut data SDKI 2012 penyebab kematian ibu akibat masalah komplikasi pada Kehamilan dan Persalinan (Kemenkes RI 2014).

Untuk menurunkan angka kematian ibu maka dilakukan asuhan persalinan normal dengan menekankan pada lima benang merah dalam memberikan asuhan persalinan, salah satunya dengan memberikan asuhan sayang ibu selama persalinan, asuhaan yang diberikan dengan menghadirkan pendamping yang selalu menemani ibu selama persalinan berlangsung (APN, 2018). Pendampingan persalinan yang dilakukan dengan menghadirkan suami untuk memberikan dukungan emosional yang membuat ibu menjadi percaya diri dan tidak takut menghadapi persalinan.

Selama proses persalinan ibu membutuhkan orang - orang terdekat yang memberikan motivasi dan kasih sayang yang lebih sehingga membantu kelancaran proses persalinan (Sari, 2014). Dengan adanya pendampingan persalinan membuat keadaan menjadi lebih baik dan membantu mengurangi obat penghilang nyeri persalinan (Nolan, 2010).

Pemerintah juga membuat program suami siaga dengan tujuan meningkatkan peran suami. Dengan membentuk pendampingan ibu yang dilakukan oleh suami, suami siap untuk persiapan biaya, siap mengantar istri pemeriksaan kehamilan 
dan persalinan, siap menjaga serta menemani istri bersalin ( Nazriah, 2010).

Dalam penelitian Rilyani 2015 yang berjudul Hubungan Pendampingan Suami dengan Tingkat Kecemasan Ibu Bersalin (Kala I) di Ruang Bersalin Rumah Sakit Pertamina Bintang Amin Bandar Lampung menunjukkan bahwa ada hubungan pendampingan suami dengan kecemasan ibu dalam proses persalinan sehingga perlu dihadirkan suami untuk mendampingi istri selama proses persalinan berlangsung.

Seorang suami harus mendampingi istri selama proses persalinan berlangsung karena pengeluaran energi yang banyak membuat istri membutuhkan perhatian dan kasih sayang, dengan menghusap keringat memberi makanan, minuman, semangat selama mengejan membuat ibu menjadi lebih senang dan bersemangat sehingga proses persalinan dapat berjalan dengan lancar dan singkat (Siwi, 2011).

Dari hasil penelitian Siwi tentang hubungan Pengetahuan dengan pendampingan persalinan oleh suami pada ibu Primipara di Desa Protomulyo 2011 bahwa pengetahuan berhubungan dengan kesiapan suami dalam melakukan pendampingan persalinan istri. Sikap suami juga mempengaruhi pendampingan istri dalam proses persalinan ditunjunkkan dari 103 responden $98 \%$ mempunyai sikap positiv dalam pendampingan dan $10 \%$ memiliki sikap negatif. Hasil penelitian tersebut menunjukkan bahwa suami bersedia melakukan pendampingan jika memiliki keyakinan, kesiapan dan kepercayaan diri.

Tidak semua Rumah Sakit, pelayanan kesehatan lainnya dan suami menyadari pentingnya kehadiran pendamping selama persalinan. Dari studi kasus yang dilakukan di klinik bersalin MIMI dari 5 pasien persalinan 3 tidak didampingi suami dikarenakan suami takut, cemas dan tidak tega melihat istri menangis ketakutan serta tidak tahu apa yang harus dilakukan selama proses persalinan berlangsungdan ada suami sedang bekerja sehinga tidak dapat menemani. Berdasarkam permasalahan di atas peneliti tertarik untuk meneliti Hubungan Pengetahuan Dan Sikap Pendampingan Suami Terhadap Istri Dalam Persalinan.

\section{METODE}

Penelitian ini bersifat deskriptif cross sectional yang dilakukan di Klinik Besalin MIMI pada bulan Maret 2018 hingga April 2018. Populasi dalam penelitian ini adalah ibu - ibu yang melakukan persalinan di klinik MIMI dengan besar sampel $30 \mathrm{ibu}$ bersalin yang memenuhi kriteria peneliti. Yang menjadi kriteria dalam penelitian adalah ibu bersalin yang bersedia menjadi subjek penelitian. Data hasil penelitian diperoleh dengan mengumpulkan data primer yang diambil saat penelitian dilakukan dengan menggunakan kuesioner. Variabel yang akan diteliti adalah umur, pekerjaan, pendididikan, pengetahuan, sikap dan pendampingan suami dalam persalinan. Hasil penelitian diolah dengan sistem komputerisasi dengan menggunakan SPSS dengan Chi square.

\section{HASIL}

Karakteristik Subjek Penelitian

Tabel 1. Distribusi Frekuensi Responden Berdasarkan Pendidikan

\begin{tabular}{cccc}
\hline No & Pendidikan & F & $(\boldsymbol{\%})$ \\
\hline 1 & SD & 4 & 13 \\
\hline 2 & SMP & 6 & 20 \\
\hline 3 & SMA & 11 & 37 \\
\hline 4 & PT & 9 & 30 \\
\hline & Jumlah & $\mathbf{3 0}$ & $\mathbf{1 0 0}$ \\
\hline
\end{tabular}

Berdasarkan Tabel 1 dapat diketahui bahwa mayoritas Responden berpendidikan SMA yaitu sebanyak 11 orang (37\%).

Tabel 2. Distribusi Frekuensi Responden berdasarkan Umur

\begin{tabular}{cccc}
\hline No & Umur & F & $(\mathbf{\%})$ \\
\hline 1 & $>35$ Tahun & 10 & 33 \\
\hline 2 & $20-35$ tahun & 12 & 40 \\
\hline 3 & $<20$ Tahun & 8 & 27 \\
\hline & Jumlah & $\mathbf{3 0}$ & $\mathbf{1 0 0}$ \\
\hline
\end{tabular}

Berdasarkan tabel 2 dapat diketahui bahwa mayoritas responden berusia $>35$ tahun (40\%).

Tabel 3. Distribu Frekuensi Berdasarkan Pekerjaan

\begin{tabular}{cccc}
\hline No & Pekerjaan & F & $(\mathbf{\%})$ \\
\hline 1 & Pedagang & 4 & 13 \\
\hline 2 & Wiraswasta & 8 & 27 \\
\hline 3 & Petani & 6 & 20 \\
\hline 4 & PNS & 7 & 23 \\
\hline 5 & Karyawan swasta & 5 & 17 \\
\hline & Jumlah & $\mathbf{3 0}$ & $\mathbf{1 0 0}$ \\
\hline
\end{tabular}


Berdasarkan tabel 3 dapat diketahui bahwa mayoritas pekerjaan responden wiraswasta sebanyak 8 orang (13\%).

Tabel 4. Distribusi Frekuensi Berdasarkan Pengetahuan

\begin{tabular}{cccc}
\hline No & Pengetahuan & F & $(\boldsymbol{\%})$ \\
\hline 1 & Baik & 9 & 30 \\
\hline 2 & Cukup & 13 & 43 \\
\hline 3 & Kurang & 8 & 27 \\
\hline & Jumlah & $\mathbf{3 0}$ & $\mathbf{1 0 0}$ \\
\hline
\end{tabular}

Tabel 4 menunjukkan mayoritas responden memiliki pengetahuan cukup sebanyak 13 orang $(43 \%)$ dan minoritas baik sebanyak 8 orang $(27 \%)$.

Tabel 5. Distribusi Frekuensi Berdasarkan Sikap

\begin{tabular}{cccc}
\hline No & Sikap & F & $(\boldsymbol{\%})$ \\
\hline 1 & Positiv & 18 & 60 \\
\hline 2 & Negativ & 12 & 40 \\
\hline & Jumlah & $\mathbf{3 0}$ & $\mathbf{1 0 0}$ \\
\hline
\end{tabular}

Tabel 5 menunjukkan mayoritas responden memiliki Sikap Positive sebanyak 18 orang $(60 \%)$ dan minoritas Negativ sebanyak 12 orang $(40 \%)$.

Tabel 6. Distribusi Pendampingan Suami salam Persalinan dalam Persalinan

\begin{tabular}{cccc}
\hline No & Pendampingan & F & $(\mathbf{\% )}$ \\
\hline 1 & Ada & 16 & 53 \\
\hline 2 & Tidak Ada & 14 & 47 \\
\hline & Jumlah & 30 & 100
\end{tabular}

Tabel 6 menunjukkan mayoritas suami mendampingi istri persalinan 16 orang $(53 \%)$.

Tabel 7. Tabulasi Silang Pengetahuan dan Sikap dengan Pendampingan Suami dalam Persalinan.

\begin{tabular}{|c|c|c|c|c|c|}
\hline \multirow{2}{*}{ No } & \multirow{2}{*}{$\begin{array}{c}\text { Tabulasi } \\
\text { Silang } \\
\end{array}$} & \multicolumn{2}{|c|}{ Pendampingan } & \multirow{2}{*}{-TOTAL } & \multirow[b]{2}{*}{$\mathbf{p}$} \\
\hline & & Ada & Tidak Ada & & \\
\hline \multirow{5}{*}{1} & Pengetahuan & & & & \\
\hline & Baik & 8 & 1 & 9 & 0.001 \\
\hline & Cukup & 8 & 5 & 13 & \\
\hline & Kurang & 0 & 8 & 8 & \\
\hline & Jumlah & 16 & 14 & 30 & \\
\hline \multirow{4}{*}{2} & Sikap & & & & \\
\hline & Positiv & 16 & 2 & 18 & 0.000 \\
\hline & Negativ & 0 & 12 & 22 & \\
\hline & Jumlah & 16 & 14 & 30 & \\
\hline $\begin{array}{l}\text { hub } \\
\text { pen } \\
0.0 \\
\text { hub } \\
\text { per }\end{array}$ & $\begin{array}{l}\text { Tabel } 7 \\
\text { ungan } \\
\text { dampingan } \\
\text { 1 Untuk S } \\
\text { ungan sika } \\
\text { salinan deng }\end{array}$ & $\begin{array}{l}\text { men } \\
\text { penget } \\
\text { persalin } \\
\text { ikap m } \\
\text { p den }\end{array}$ & $\begin{array}{l}\text { unjukkan } \\
\text { ahuan } \\
\text { an dengan } 1 \\
\text { enunjukkan } \\
\text { gan penda } \\
p=0.000 \text {. }\end{array}$ & $\begin{array}{r}\text { adanya } \\
\text { dengan } \\
\text { ailai } \mathrm{p}= \\
\text { adanya } \\
\text { mpingan }\end{array}$ & \\
\hline
\end{tabular}

\section{PEMBAHASAN}

Hasil Penelitian pada tabel 1 menunjukkan distribusi frekuensi responden berdasarkan karakteristik responden subjek penelitian, dimana hasil menunjukkan mayoritas usia responden berada pada rentang usia 20-35 tahun. Menurut Penelitian Adenike 2013 menjelaskan laki - laki yang berusia 20-39 tahun memiliki kesadaran tentang kesehatan maternal pasangannya. Sesuai dengan penelitian Juwita tahun 2014 memberikan dukungan kepada istri dalam pendampingan persalinan. Hasil penelitian menunjukkan pendidikan responden SMA. Notoatmodjo 2010 mengungkapkan pengetahuan menjadi faktor predesposisi terhadap perubahan prilaku, pendidikan juga mempengaruhi pengetahuan dan sikap. Dalam penelitian menunjukkan pekerjaan responden mayoritas berwirausaha hanya sebagian kecil yang memiliki profesi sebagai petani. Pekerjaan mempengaruhi pengetahuan dan sikap (Notoatmojdo, 2010).

Hal ini menunjukkan pengetahuan dan sikap pendampingan suami dalam persalinan dipengaruhi oleh pendidikan, umur dan pekerjaan suami. Maka semakin tinggi ppendidikan seseorang maka semakin memiliki pengetahuan yang dan sikap yan baik. Pendidikan juga membuat seseorang semakin ingin mengetahui berbagai macam hal terutama yang berkaitan dengan kesehatan pasangannya.

Tabel tabulasi silang antara Pengetahuan dengan Pendampingan Suami dalam persalinan menunjukkan pengetahuan responden yang baik dan cukup membuat suami melakukan pendampingan selama proses persalinan berlangsung. Hal ini dapat diketahui dengan hasil nilai $\alpha=0.001$ yang menunjukkan adanya hubungan pengetahuan dengan pendampingan suami terhadp persalinan. Dalam penelitian Rilyani 2015 menunjukkan dukungan suami sangat penting dalam menghadapi proses persalinan yang panjang dan melelahkan, dukungan yang timbul dari suami karena adanya pengetahuan suami. Dalam penelitian Siwi 2011 menunjukkan adanyan hubungan pengetahauan dengan pendampingan suami dalam persalinan.

Dalam Penelitian Anggraeni 2014 menjelaskan bahwa ketrlibatan suami 
sangat diperlukan selama proses persalinan dengan memberikan dorongan dan kenyamanan sehingga dapat mengurangi kecemasan dan stress.

Pada hasil penelitian tabel silang antara sikap dengan pendampingna suami dalam persalinan menunjukkan sikap responden yang positiv memiliki hubungan dengan pendampingan persalinan. Hal ini dapat diketahu dari nilai $\alpha=0.000$. Sikap positive suami dalam pendampingan persalinan merupakan dukungan yang diberikan kepada ibu sehingga dapat merasa nyamn dan sayangi. Sholihah 2010 menyatakan bahwa suami yang hadir mendampingi istri bersalin akan mendapat pengalaman dan pelajaran yang berharga dengan melihat proses persalinan berlangsung. Dalam teori yang diungkapan oleh Sari dkk, 2014 bahwa peran serta orang terdekat dengan menunjukkan sikap yang positiv sangat besar pengaruhnya terhadap psikologi ibu bersalin yang sangata membutuhkan dorongan dan kasih sayang sehingga dapat memperlancar proses persalinan yang aman dan nyaman. Kehadiran suami dalam persalinan membuat ibu semakin kuat dalam menghadapi rasa sakit dan kecemasan serta memiliki motivasi untuk melahirkan bayinya dengan cepat dan semangat.

\section{KESIMPULAN}

Berdasarkan hasil penelitian tentang Hubungan Pengetahuan Dan Sikap Pendampingan Suami Terhadap Istri Dalam Persalinan maka dapat disimpulkan:

1. Distribusi frekuensi umur mayoritas responden berusia 20-35 tahun sebanyak 12 orang (40\%)

2. Distribusi frekuensi berdasarkan Pendidikan Mayoritas responden berpendidikan SMA sebanyak 11 orang $(37 \%)$

3. Distribusi frekuensi responden berdasarkan pekerjaan mayoritas responden bekerja sebagai wiraswasta sebanyak 8 orang (27\%)

4. Distribusi Frekuensi Responden berdasarkan pengetahuan mayoritas responden berpengetahuan cukup sebanyak 13 orang (43\%)

5. Distribusi responden berdasarkan Sikap mayoritas responden memliki sikap positiv sebanyak 18 orang $(60 \%)$
6. Distribusi Pendampingan Suami mayoritas suami ada mendampingi persalinan sebanyak 16 orang (53\%)

7. Distribusi Hubungan pengetahuan dan Sikap pendampingan suami dalam persalinan yaitu adanya hubungan pengetahuan dan sikap dalam pendampingan suami istri dalam persalinan dikatahui dengan nilai $\mathrm{p}=$ 0.001 untuk pengetahuan dan $\mathrm{p}=$ 0.000 untuk sikap.

\section{SARAN}

Perlu ditingkatkan Pengetahuan dan Sikap suami dalam persalinan karena dengan adanya pendampingan suami membuat ibu bersalin merasa disanyangi dan semakin semangat dalam mengahadapi persalinan. Petugas kesehatan perlu meningkatkan peran suami dalam pendampingan persalainan istri dengan memberikan informasi terkait persalinan dan hal-hal yang diperlukan. Bagi peneliti selanjutnya dapat meningkatkan penelitian yang berkaitan dengan pendampingan persalinan dengan desain penelitian yang lebih baik.

\section{DAFTAR PUSTAKA}

Adenike, O.B., O Ester, A.O., O Adefisoye, A.A, A AdeleyeA., dan O Sunday, O. (2013) Perceptiom, attitude and invlvement of men in maternal health care in a Nigerian Community. Journal of Public Health and Epideiologi.

Anggraeni, Diana Septi; Sumarni, Elly Eko Agustina. (2014). Pengaruh Dukungan Suami Dalam Persalinan dengan Nyeri Persalinan Di RSIA Bunda Arif Purwokerto.ojs.akbidylpp.ac.id/index. php/Prada/article/download/87/77.

APN, (2014). Buku Acuan Persalinan Normal. Jakarta: JNPK.

Kemenkes RI. (2014). Infodatin. www.pusdatin.kemekes.go.id.

Nazriah. (2010). Konsep Dasar Kebidanan. Banda Aceh: yayasan Pena.

Nolan, Mary. (2010). Kelas Bersalin. Yogyakarta: Golden Books.

Notoatmodjo, Soekidjo. (2010). Kesehatan Masyarakat. Jakarta: Rineka Cipta.

Rilayani. (2015). Hubungan Pendampingan Suami dengan Tinkat Kecemasan Ibu Bersalin (KalaI) di Ruang Bersalin 
Rumah Sakit Pertamina Bintnag Amin Bandar Lampung. http://ejurnalmalahayati.ac.id/index.ph $\mathrm{p} /$ holistik/article/view/15.

Sari, Puspita Eka \& Rimandani Dwi Kurnia. (2014). Asuhan Kebidanan Peralinan (Intranatal care). Jakarta: Trans Info Media.

Sholihah. (2010). Persiapan dan Strategi Mengahadapi Persalinan Sehat dan Alamiah. Jakarta: Diva Press.

Siwi, R.T. (2011). Hubungan Pengetahuan dengan Pendampingan Persalinan oleh Suami pada Ibu Primipara di Desa Protomulyo, Kaliwungu Selatan. http://stikeswh.ac.id:8082/journal/inde x.php/jitk/article/view/80.

Tarsikah, Herman Susanto, Herri S. Sastramihardja. (2012). Penurunan Nyeri Persalinan Primigravida Kala I Fase Aktif Pascapenghirupan Aromaterapi Lavender Journal. fk.unpad.ac.id/index.php/mkb/article/v iew/210.

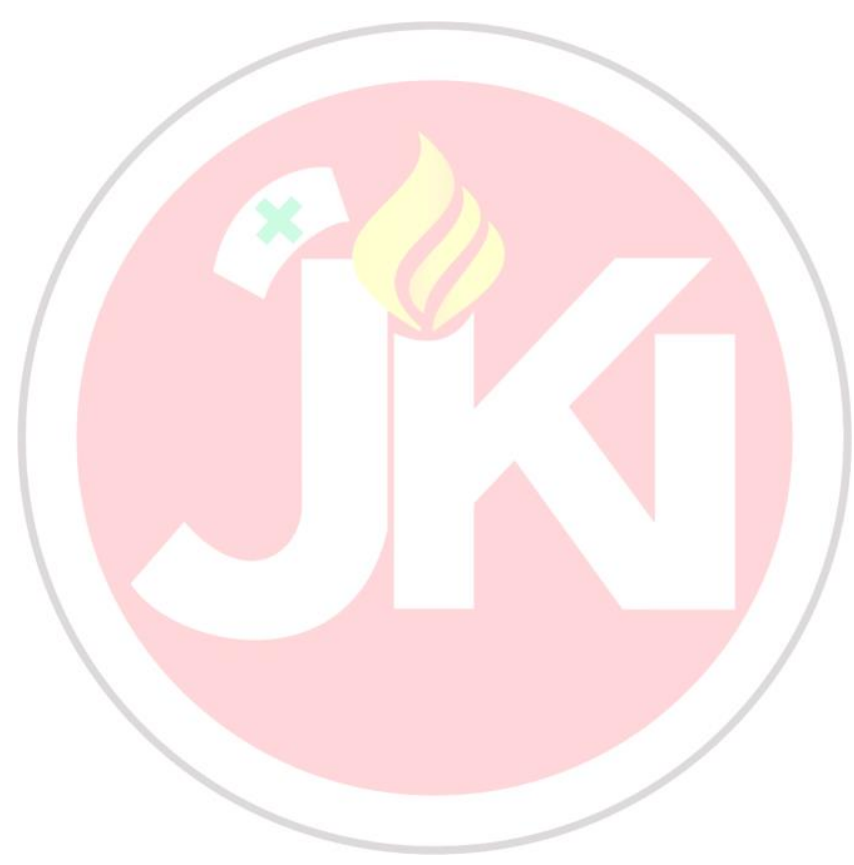

